\title{
Investigating pupils' group creativity in drama - Teacher trainees fostering a creative classroom environment
}

\author{
Tapio Toivanen, Laura Halkilahti \\ Department of Teacher Education, University of Helsinki, \\ Box 8, 00014 University of Helsinki, Finland \\ tapio.toivanen@helsinki.fi
}

\begin{abstract}
The use of drama in education can be seen as a method to support pupils' creativity. Drama work offers possibilities for creative group processes and aims for deeper conceptual understanding by preparing students to create new knowledge. Having said this, it is difficult to determine whether this is true, and in what way if it is true. This article seeks to answer the following research questions: Can the principles of theatrical improvisation be used as an analytic tool to examine the collaboration and emergence of creative ideas between pupils during drama work? To what degree do teacher trainees succeed in supporting pupils' group creativity in drama lessons? The potential complexity and diversity of creative group processes in drama education is challenging for teacher trainees and novice teachers at the beginning of their careers. In this study teacher trainees specializing in drama were observed. Eight lessons were recorded and analyzed using the core principles of improvisation as an analytic tool. The scenes were then interpreted to recognize the characteristics of group creativity (improvisation, collaboration and emergence) defined by Sawyer (2003, 2006, 2012). Both authors analyzed and made their interpretations separately. The findings were compared and the few situations where the authors' opinions differed were reconciled by discussion. The research results show that the analysis method based on the principles of improvisation was moderately usable for both exact and more general analysis. Within the restrictions of the case studies, our conclusion is that drama teaching supports pupils' group creativity.
\end{abstract}

\section{Indexing terms/Keywords}

teacher education, group creativity, improvisation, drama, drama teaching

\section{Academic Discipline And Sub-Disciplines}

Education; teacher education, drama education

\section{SUBJECT CLASSIFICATION}

E.g., Mathematics Subject Classification; Library of Congress Classification

\section{TYPE (METHOD/APPROACH)}

Case study, videoanalyze

\section{Council for Innovative Research}

Peer Review Research Publishing System

\section{Journal: INTERNATIONAL JOURNAL OF RESEARCH IN EDUCATION METHODOLOGY}

Vol 5, No. 3,

www.ijrem.com , ijremeditor@gmail.com 
In the research project "The challenge of empty space" at the University of Helsinki's Department of Teacher Education we have outlined drama as a pupil-active, experiential and socio-constructive way of aesthetic learning (see Toivanen 2013; Toivanen, Pyykkö \& Ruismäki 2011; Toivanen, Mikkola \& Ruismäki 2012b; Toivanen \& Pyykkö 2012c\&d; Toivanen, Halkilahti \& Ruismäki 2013a; Toivanen \& Kaasinen 2013b). In our study of creative pedagogy (Toivanen, Halkilahti \& Ruismäki 2013a), we delineate the context of drama tuition (a creative environment) as a stage where there is space for individual creativity and particularly collective group creativity to emerge. The teacher's role in drama is to create the creative environment, which facilitates the pupils' drama work, engages pupils in action and encourages them to find their own creative solutions.

Group creativity is simply defined as a creative process or product created by a group, organization or another ensemble (Sawyer 2003; 2012a, 231). Group creativity differs from individual creativity by its interactive and dialectic nature. However, the creative process of creative individuals diverges from the creativity manifested collectively, even though the creative individuals are in connection with the existing social and cultural environment (Sawyer 2003, 25; 2012b). Group creativity is not the sole property of artists or scientists; it can also be seen as a phenomenon of everyday life from children's play (e.g., Sawyer 1997; Lobman 2003; Dunn 2008) to working organizations (e.g., Turner 2008). We have chosen Craft's $(2001,45)$ concept of 'little c creativity', LCC, as our main concept to define children's creativity and creative learning (Toivanen et al., 2013a) in drama. According to Kampylis et al. (2009, 18), LCC could be widely applied in the primary school context because it is regarded as an innate potential in all people. Also Craft (2001) points out that a little creativity can be developed in every person. Children are always open to new experiences and have a habit of being interested in everything new (Lin 2011). Creative ideas are an outcome of collaboration in group creativity. Solving problems with available forms of drama (Neelands \& Goode 2011) in the classroom is an example of group creativity (e.g. Toivanen et al., 2013a; McLauchlan 2010; Karakelle 2006; Hui \& Lau 2006).

Studying group creativity is an attempt to understand the creative potential of the group. Since group potential is dependent on individual skills within the group, studies have aimed to discover the relation between individual capacity and group creativity (Kurtzberg 2005). Pirola-Merlo and Mann (2004) state that very little research has been done on the individual contribution to the creative processes of groups. They explain that the lack of research is due to the challenge of generalizing because individual creative solutions always depend on the situation and the task. On the other hand, the problematic relation between individual and group creativity is brought about by variable definitions of creativity. Group creativity is different from individual creativity, so studying them together as one object is demanding. Therefore, research is still focused on group creativity as a complete phenomenon without isolating the individual contributions of single group members in the creative process (Kutzberg 2005; Pirola-Merlo \& Mann 2004). The same collective aspect is seen in drama learning; the drama process is a result of thinking, communication and actions between the members of the group as they produce answers to problems or create fictional events. Group creativity and the concept of creativity as a process are essential for drama learning (cf. Sawyer 2003, 26).

Sawyer $(2006,148)$ defines three characteristics of group creativity in both music and theater. They are improvisation, collaboration and emergence. He highlights $(2006,161)$ the fact that if creativity is central to education, our educational methods should emphasize group interaction. According to Sawyer (2003a; 2006, 162), when groups of pupils engage in guided participation, in this case drama, the flow of interaction and improvisational actions emerge from the successive individual contributions of the participants. He calls this process collaborative emergence, because a group's properties and outcomes emerge from individual actions and interactions. Emergence is a "creation of something new that was unpredictable, even given a full and complete knowledge of the world prior to its emergence" (Sawyer 2012, 63).

The world famous Finnish teacher education system aims to train autonomous teachers who plan their own teaching and emphasize the importance of teachers' pedagogical thinking and reflection. These requirements are rehearsed in theoretical and practical studies in the master's degree curriculum (Jyrhämä \& Maaranen 2012, 97-98). Our research project has established that the potential complexity and diversity of creative learning processes in drama education are challenging for trainee and novice teachers (e.g. Toivanen et al., 2012b, c, d). One of the problems associated with teaching that supports creativity is that the teacher trainees usually follow exact lesson plans, therefore rather than being reflective and improvisational practitioners, they tend to function as actors reading from a manuscript (Tanggaard 2011; Konstantinidou et al., 2013). Strict adherence to the lesson plan can lead to a lack of presence and spontaneity in pedagogical interaction between the teacher and the pupils. When teachers do not interact responsively to the pupil's proposals but ignores, interprets, or dominates their activity (Sawyer 2004, 2006, 2012; Toivanen \& Kaasinen 2013b; Toivanen et al., 2012b), the teacher does not create a learning atmosphere that supports creativity. The challenges for teacher education are: How can we prepare future teachers to teach drama creatively and support pupils' creativity? How can we be sure that drama-teaching skills provided by teacher education are implemented in a teacher's work? Does the lack of teaching experience make creative drama teaching challenging?

\section{Study design}

In this article, we have taken Sawyer's $(2003,2006,2012)$ three characteristics of group creativity; collaboration, improvisation and emergence, as basis factors for our study of group creativity in drama. We are interested in testing whether a tool based on the principles of theatrical improvisation can be used to describe and analyze the rich, complex nature of interactions in group creative processes (cf. Lobman 2005, 2006). In addition, we want to study how many activities that support group creativity occur during drama lessons taught by teacher trainees. What kinds of drama techniques support pupils' group creativity; i.e., collaboration, improvisation and the emergence of ideas between pupils? How often do they take place as an ongoing activity in the classroom drama?

By collaboration we mean interaction between the pupils. This can be both verbal and nonverbal. The creative solution produced cannot be associated with one member of the group. All the members of the group contribute their part to the 
solution and their interactional dynamics produce the solutions in the drama work. Creative group activities provide different participation levels from peripheral participation to a more central role.

Improvisation refers to possibilities to create and share ideas between group members at any moment. Sharing ideas takes place both verbally and physically. The pupils work together rather than focusing on their own individual ideas. Working together includes making suggestions and mistakes, before the ideas transform into a cohesive, improvised solution.

The emergence of solutions is unpredictable and hard to explain in the terms of the group components. When groups of pupils work well together, the solutions they create collectively are greater than the sum of their individual ideas.

The research questions are:

1. How can the principles of theatrical improvisation work be used as an analytic tool to examine the collaboration, improvisation and emergence of ideas between the pupils in drama?

\section{How many drama lessons taught by teacher trainees include activities that support pupils' group creativity?}

Barron and Engle $(2007,33)$ state that good questions help to maintain perspective during video analysis and prevent researchers from getting lost in detail. The video data for the second research question was collected in the teacher training school of the University of Helsinki. The pupils were from the 1-4 grades of lower comprehensive school. The material contained 21 videotaped drama lessons taught by a single or pair of class teacher trainees from the University of Helsinki Class Teacher Education program. The video data was collected during spring 2011, 2012 and autumn 2013. Each of these 21 drama lessons was recorded with the permission of the teacher trainees and the pupils' parents. The video camera was placed at the rear of the classroom. The camera position, i.e., shooting from the back, was consistent with this study's focus on student's interaction (Erickson 2006). Video data as research material is suitable for the systematic analysis of a pupil's action during a teaching event especially when examining a complete system of interaction (Heath 1997; Erickson 2006).

For this article, we analyzed eight videotaped drama lessons. The study omitted lessons where the pupils were learning the basics of improvisation (8 lessons) or where the trainee teachers where not specialized in drama (5 lessons). The selected lessons included process drama that combined two powerful learning methods through drama, story and roleplay. These lessons contained a variety of drama techniques that allowed pupils to explore themes in different ways while proposing and testing alternative solutions. Taking roles also invites them to use their imagination and become aware of other people's circumstances. By including drama techniques in lesson planning, the teacher offers the pupils multiple settings to work in pairs, in small groups and as a class (Dickinson \& Neelands 2006, 13, 31-32).

All the teacher trainees involved in this study were specialized in drama education (they had completed 25 study points). In Case 1 the teacher trainee was solely responsible for the tuition. In other cases the teacher trainees worked in pairs with one teaching while the other was assisting. The second trainee was "floating" in the group while the primary teacher trainee was leading the activity by herself (Pianta, La Paro \& Hamre 2008, 11).

Both members of the research team made their own content log based on the time indexing for recorded lesson material. The time indexes included lesson duration, duration of different phases of the lesson (warm up game, drama techniques, ending or reflection on the lesson). Both researchers also tried to identify and evaluate the drama work that supported group creativity. Afterwards, the team members compared the evaluation results. Parallel video analyses were made to improve the reliability of the study (Barron \& Engle 2007).

\section{Improvisation as an analytic tool of group creativity}

The video data was analyzed by using basic improvisational principles as an analytic tool. The tool was tested beforehand in a case study that examined creative group processes in a lower level comprehensive school theater project in southern Finland during the autumn of 2012 (Halkilahti 2013). In the case study, 29 fifth and sixth graders participated in a voluntary theater project. The play was directed by a male class teacher who was drama teacher specializing in play back theater. The group was preparing the play with the so-called devising method (Heddon \& Milling 2006, 3-10). Devising in this case meant the use of drama techniques, play back theatre and improvisation as a help to create the play. The other writer of this article (Halkilahti) observed and videotaped the classes throughout the autumn from August to December to improve the reliability of the case study. Yin (2002) states that it is necessary to employ a study design that allow the researchers to become familiar with the daily lives and experiences of the participants if their focus is on a contemporary phenomenon with some real-life context.

The research material includes notes and videotapes from eight meetings and was analyzed as suggested by Spiers (2004). The analytic tool followed Lobman's $(2005,2006)$ previous studies about the interaction between kindergarten teachers and children. First, the video data was viewed a couple of times to discover the most relevant parts of the data. Second, selected parts were transcribed and observation notes were carefully added. The transcriptions included both verbal and nonverbal actions because in improvisation accepting offers can also be physical. Third, the data was analyzed by identifying the basic elements of improvisation. In her data analysis, Lobman $(2005,2006)$ used three core principles of improvisation, the giving and accepting of offers, "Yes, and" and "Don't negate". In our studies, we separated the giving and accepting of offers into two different actions and added listening as our fifth principle. The five elements of improvisation used in the data analysis were listening, giving offers, accepting offers, "Yes, and" and negation. These five elements were chosen because of three reasons; first, improvisation requires listening and concentration on the situation. Second, it is built up by offering ideas and accepting others' ideas and building on them (the "Yes, and" principle). On the other hand, improvisation cannot progress if the ideas are negated. (Johnstone 2007, 94-100; Spolin 1999.) The last step 
of the analysis included interpreting each action carefully. When identifying the basic improvisational principle, it is essential to consider the context. In one situation staying still might refer to the basic improvisational element of listening. In another situation, it might refer to negating.

To demonstrate these characteristics we present an example of group creativity from the research material (Table 1). All the research material was not analyzed as carefully as this situation in Table 1. Starting from the left, the first cells describe the transaction and simultaneous events are in the same cell. The next column to the right contains the observation notes that explain the action. The next column contains interpretations that describe the basic element of improvisation seen in the transaction. The rightmost column contains the situation analyzed into one or more characteristics of group creativity.

The example is from case 4 and lasts for only 30 seconds. The class was divided into groups of four pupils, which were working at the same time. The pupils were supposed to make moving statues illustrating frustration. In the example presented in Table 1, most of the offers are physical and the situation does not include verbal communication between the pupils.

TABLE 1. An example of an exact video data analysis.

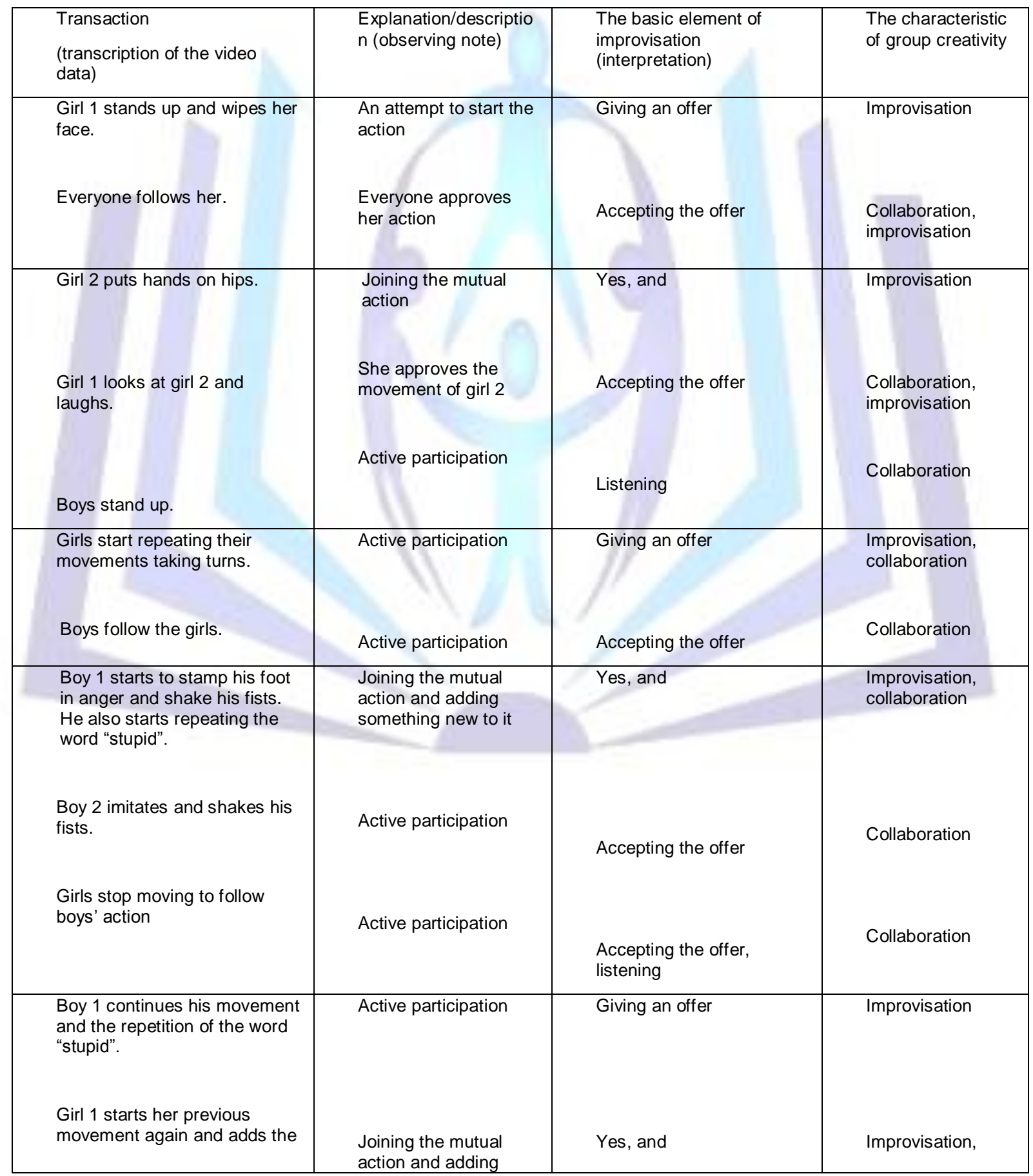




\begin{tabular}{|c|c|c|c|}
\hline word "silly" & something new to it & & collaboration \\
\hline $\begin{array}{l}\text { Boy } 2 \text { starts to repeat his own } \\
\text { movement of slumping down } \\
\text { in frustration }\end{array}$ & $\begin{array}{l}\text { Joining the mutual } \\
\text { action }\end{array}$ & Yes, and & $\begin{array}{l}\text { Improvisation, } \\
\text { collaboration }\end{array}$ \\
\hline $\begin{array}{l}\text { Girl } 2 \text { follows everyone else for } \\
\text { a while. }\end{array}$ & Passive participation & & \\
\hline $\begin{array}{l}\text { Girl } 2 \text { starts making her } \\
\text { previous movement }\end{array}$ & Active participation & Accepting the offers & Collaboration \\
\hline $\begin{array}{l}\text { Everyone makes their own } \\
\text { movements but follow the } \\
\text { others at the same time }\end{array}$ & $\begin{array}{l}\text { Active collaboration, } \\
\text { working well together }\end{array}$ & $\begin{array}{l}\text { Accepting the offers } \\
\text { constantly, listening }\end{array}$ & Emergence \\
\hline
\end{tabular}

The group situation analyzed and presented above (Table 1) shows a group that works extremely well together. It is rather easy to find the basic principles of improvisation and therefore the characteristics of group creativity in their working. There is only one situation in the third row from the end, where Girl 2 is passive and does not join the others' action imm ediately. However, even though she only follows the others after a while, she does not negate the others' ideas. After some time she even accepts the physical offers by joining the action, which is why this situation was not interpreted as negation. Except for this one situation, all the offers are accepted instantaneously and the group members also build the situation forward from others' offers. Due to the fluent improvisation and collaboration, it was even possible to find the emergence of ideas at the end of this creative group situation.

\section{Findings}

Each of the eight-videotaped lessons was analyzed by both authors. The analyses included discussion of whether the analytical framework captured all the important aspects of group creativity; collaboration, improvisation and emergence. These aspects and the basic elements of improvisation were identified from the pupils' actions and interaction with each other (Moeller Andersen \& Lund Nielsen 2011). A few of the eight lessons (marked with *) have been studied in previous research articles. In those earlier studies, the focus was on the structural factors in a group (Toivanen \& Pyykkö 2012d) and on the interaction between the teacher trainees and the pupils during drama lessons (Toivanen et al., 2012b). In this study the analysis (see Table 2) was executed by dividing the drama lessons into separate scenes; instructions and waiting time, warm up games, various drama techniques and ending the lesson. When it was relevant to the analysis, the activities were also named precisely. The duration of each activity was measured carefully. Lessons in Finnish lower grade of comprehensive schools usually last 45 minutes. However, the actual drama working time varied between 32 and 45 minutes as it took time to move from recess to a classroom or to another working place and start work.

Table 2. The video analyzed drama lessons 


\begin{tabular}{|c|c|c|c|c|c|}
\hline $\begin{array}{l}\text { Case } \\
\text { (Grade) }\end{array}$ & $\begin{array}{l}\text { Scenes - structure of the } \\
\text { drama lesson (Activities that } \\
\text { support group creativity are } \\
\text { in bold) }\end{array}$ & $\begin{array}{l}\text { Duration of } \\
\text { the drama } \\
\text { lesson (Exact } \\
\text { duration) }\end{array}$ & $\begin{array}{l}\text { Instructions } \\
\text { and } \\
\text { waiting time } \\
\text { (Percentage } \\
\text { from the } \\
\text { lesson } \\
\text { duration) }\end{array}$ & $\begin{array}{l}\text { Active } \\
\text { drama } \\
\text { working time } \\
\text { (Percentage } \\
\text { from the } \\
\text { lesson } \\
\text { duration) }\end{array}$ & $\begin{array}{l}\text { Working time that } \\
\text { supports group } \\
\text { creativity } \\
\text { (Percentage from } \\
\text { the whole } \\
\text { lesson/active } \\
\text { working time) }\end{array}$ \\
\hline $\begin{array}{l}\text { Case } 1 \\
\qquad\left(1^{\text {st }}\right. \\
\left.\text { grade }^{*}\right)\end{array}$ & $\begin{array}{l}\text { warm-up game, Who is } \\
\text { leading the movement - } \\
\text { game, hot-seating, small } \\
\text { group drama, showing } \\
\text { scenes to the others, } \\
\text { spectrum of difference }\end{array}$ & $\begin{array}{c}\sim 43 \mathrm{~min} \\
(42 \mathrm{~min} 57 \mathrm{sec})\end{array}$ & $\begin{array}{c}\sim 15 \min \\
(35 \%)\end{array}$ & $\begin{array}{l}\sim 28 \min \\
(65 \%)\end{array}$ & $\begin{array}{l}\sim 25 \min \\
(58 / 89 \%)\end{array}$ \\
\hline $\begin{array}{l}\text { Case } 2 \\
\qquad\left(1^{\text {st }}\right. \\
\text { grade })\end{array}$ & $\begin{array}{l}\text { Revision of the drama } \\
\text { contract and moving tables, } \\
\text { reviewing previous events in } \\
\text { process drama, warm-up } \\
\text { game, remembering earlier } \\
\text { solutions and selecting } \\
\text { one to use, still images } \\
\text { (whole group), telling and } \\
\text { acting (whole group), } \\
\text { teacher storytelling and } \\
\text { demonstration, a game, } \\
\text { voting and still images, } \\
\text { telling and acting (whole } \\
\text { group), 2x telling and } \\
\text { acting (whole group), } \\
\text { creating a soundscape in } \\
\text { three groups, listening to } \\
\text { the soundscapes, } \\
\text { spectrum of difference }\end{array}$ & $\begin{array}{l}\sim 40 \mathrm{~min} \\
(39 \min 35 \mathrm{sec})\end{array}$ & & $\begin{array}{l}\sim 31 \mathrm{~min} \\
(78 \%)\end{array}$ & $\begin{array}{l}\sim 17 \min \\
(43 / 54 \%)\end{array}$ \\
\hline $\begin{array}{l}\text { Case } 3 \\
\qquad\left(2^{\text {nd }}\right. \\
\left.\text { grade }^{\star}\right)\end{array}$ & $\begin{array}{l}\text { Warm-up game of telling and } \\
\text { acting, action narration, } \\
\text { storytelling, doing still } \\
\text { images in group, showing } \\
\text { still images to the others, } \\
\text { reflection of the lesson }\end{array}$ & $\begin{array}{c}\sim 32 \min \\
(32 \min 25 \mathrm{sec})\end{array}$ & $\begin{array}{l}\sim 6 \min \\
(19 \%)\end{array}$ & $\begin{array}{c}\sim 26 \min \\
(81 \%)\end{array}$ & $\begin{array}{l}\sim 15 \min \\
(47 / 57 \%)\end{array}$ \\
\hline $\begin{array}{l}\text { Case } 4 \\
\left(2^{\text {nd }}\right. \\
\left.\text { grade }^{\star}\right)\end{array}$ & $\begin{array}{l}\text { Role on the wall, storytelling, } \\
\text { warm-up game, } \\
\text { concentration game, } \\
\text { storytelling, teacher in the } \\
\text { role and collective role, } \\
\text { problem solving in groups, } \\
\text { sharing solutions, } \\
\text { storytelling, doing moving } \\
\text { statues and sharing them, } \\
\text { storytelling, plays in small } \\
\text { groups and showing them } \\
\text { to the others, ending the } \\
\text { lesson }\end{array}$ & $\begin{array}{c}\sim 45 \min \\
(44 \min 45 \mathrm{sec})\end{array}$ & & $\sim 41$ & $\begin{array}{l}\sim 20 \min \\
(44 / 49 \%)\end{array}$ \\
\hline $\begin{array}{l}\text { Case } 5 \\
\left(2^{\text {nd }}\right. \\
\left.\text { grade }^{*}\right)\end{array}$ & $\begin{array}{l}\text { Making the drama contract, } \\
\text { warm-up game, Who is } \\
\text { leading the movement - } \\
\text { game, individual } \\
\text { characterizing, still images } \\
\text { in pairs, reflection of the } \\
\text { lesson }\end{array}$ & $\begin{array}{c}\sim 40 \min \\
(39 \min 54 \mathrm{sec})\end{array}$ & $\begin{array}{c}\sim 19 \min \\
(49 \%)\end{array}$ & $\begin{array}{l}\sim 21 \min \\
(51 \%)\end{array}$ & $\begin{array}{l}\sim 10 \min \\
(25 / 48 \%)\end{array}$ \\
\hline $\begin{array}{l}\text { Case } 6 \\
\left(3^{\text {rd }}\right. \\
\text { grade })\end{array}$ & $\begin{array}{l}\text { Warm-up game of telling and } \\
\text { acting, teachers in roles } \\
\text { introducing the problem, } \\
\text { small groups reading and } \\
\text { discussion (diary texts), } \\
\text { two times hot seating, } \\
\text { meeting and voting (whole } \\
\text { group), ending the lesson }\end{array}$ & $\begin{array}{c}\sim 31 \mathrm{~min} \\
(30 \mathrm{~min} 40 \mathrm{sec})\end{array}$ & $\begin{array}{l}\sim 9 \min \\
(29 \%)\end{array}$ & $\begin{array}{l}\sim 22 \min \\
(71 \%)\end{array}$ & $\begin{array}{l}\sim 20 \min \\
(65 / 91 \%)\end{array}$ \\
\hline $\begin{array}{c}\text { Case } 7 \\
\left(4^{\text {th }}\right. \\
\text { grade })\end{array}$ & $\begin{array}{l}\text { Creating circle, warm-up } \\
\text { game, teacher reading story, } \\
\text { action narration, two groups } \\
\text { and two characters solving }\end{array}$ & $39 \min$ & $\begin{array}{l}\sim 7 \mathrm{~min} \\
(18 \%)\end{array}$ & $\begin{array}{c}\sim 32 \min \\
(82 \%)\end{array}$ & $\begin{array}{l}\sim 11 \min \\
(28 / 34 \%)\end{array}$ \\
\hline
\end{tabular}




\begin{tabular}{|c|c|c|c|c|c|}
\hline & $\begin{array}{l}\text { problem between } \\
\text { characters, creating } \\
\text { images in pairs, a game, } \\
\text { ending the lesson }\end{array}$ & & & & \\
\hline $\begin{array}{l}\text { Case } 8 \\
\qquad 4^{\text {th }} \\
\left.\text { grade }^{*}\right)\end{array}$ & $\begin{array}{l}\text { Drama contract, warm-up } \\
\text { game, action narration, } \\
\text { small groups creating } \\
\text { short plays, teacher } \\
\text { demonstration, play } \\
\text { making, practicing and } \\
\text { sharing, ending the lesson }\end{array}$ & $\begin{array}{l}\sim 37 \mathrm{~min} \\
(36 \mathrm{~min} 35 \mathrm{sec})\end{array}$ & $\begin{array}{c}\sim 10 \mathrm{~min} \\
(27 \%)\end{array}$ & $\begin{array}{l}\sim 27 \mathrm{~min} \\
(73 \%)\end{array}$ & $\begin{array}{l}\sim 14 \min \\
(38 / 51 \%)\end{array}$ \\
\hline
\end{tabular}

The time indexing (in Table 2) indicates how long the drama lesson lasted, what were the working methods (scenes) and how the time was divided between the duration of instructions and waiting time, active drama working time and working time that support pupils' group creativity. Table 2 also shows the percentage of time used in each category. Additionally, the percentage of the time that supports group creativity was calculated from both lesson duration and active working time.

Passive waiting time refers to pupils listening to instructions or waiting for the action to start. A case study (Toivanen \& Pyykkö 2012d) gave some indication about the importance of paying attention to the structural factors in a group especially when a novice teacher starts teaching classroom drama. Based on the findings from partly the same research material $(\mathrm{N}=6)$, acknowledging the group roles had a direct relation to active working time, pupils' abilities to follow the norms (drama contract) and the communication (whether the instructions are given through centralized or scattered communication). We concluded that teacher trainees have to try to break the existing group roles to make the lesson work smoother. Taking the group roles into account means more active working time for the pupils and also directly affects the amount of teacher trainee's actions needed to prevent and solve status conflicts (between the teacher and the pupils or between the pupils) during the drama lesson. (Toivanen \& Pyykkö 2012d.) The other case study (Toivanen et al., 2012b) focused on the interaction during drama lessons and the results were that teacher trainees found interactions challenging during drama lessons. Drama is a non-formal approach to teaching thus making the controlling of the group or individual pupils more difficult. The trainee teachers $(\mathrm{N}=7)$ were interviewed using the method of stimulated recall. The trainee teachers lacked confidence in their subject knowledge, reasons behind their actions, nonverbal communication and teaching skills. The feeling of inadequacy was also related to the insufficient management of pupils and the group. (Toivanen et al., 2012b.) Furthermore, Toivanen et al. (2012a) identified and explained the teaching factors that may determine the success or failure of drama lessons. This study also provided evidence that a teacher's $(N=30)$ pedagogical competence to devise the actual interactive solutions in drama lessons plays a central role in the success or failure of the drama teaching. (Toivanen et al., 2012a.) Findings of importance of teacher's ability to situation-specific solutions in earlier research can partly explain the variation of the active working time between 17 to 41 minutes during the lessons of this study. On the other hand, the number of different drama working section (methods) varied from six to fourteen indicating that the tempo of the lessons was very different as well. The lesson with six drama-working sections (Case 5) had a waiting time of 19 minutes but for the lesson with thirteen sections (Case 4) the waiting time was only four minutes.

The nature of drama education is social and experimental and it involves activities in actual creation. Bailin (2011) notes that we believe participating in drama can foster creativity. Although it is difficult to determine whether that is true and if it is in what way. This was the question we were trying to answer in this study. The active working time in studied lessons varied from $51 \%$ (21 minutes) to $91 \%$ (41 minutes). All the active working time was not supporting the group creativity even though pupils were mostly working together. Warm-up games, listening to storytelling, individual work, ending or reflecting lessons developed the pupils' abilities to work together (social skills) and engagement to drama work, but did not challenge pupils to create their own solutions. These activities included collaboration, sometimes improvisation but not the emergence of solutions, which is the reason they are excluded from the category supportive to group creativity.

In this article, creativity in drama is not only confined to spontaneous improvisation. We looked for learning situations where the students worked in pairs, small groups or as a class engaging in classroom drama activities and developing fictional events and their own solutions to the given tasks. Creative working in a group during drama includes the following elements; communication, negation, planning, agreement, improvisation, working in a role and presentation solutions to others. During the drama lessons in this study, the time used for supporting group creativity varied from 10 to 20 minutes, which was between $25 \%$ and $65 \%$ of the duration of the drama lesson. Creative group work covered $34 \%$ to $91 \%$ of the active working time. In most cases it was more than half of the active working time. Analysis did not concentrate on the quality of the creative work. We did not evaluate the level of individual student engagement or the quality and originality of the solutions. Group creativity was simply defined as a process with the selected five elements; first, pupils listening and concentrating on the situation. Second, pupils offering ideas and accepting other's ideas and building on them (the "Yes, and" principle), which produces an output to a task given to a pair or a group (see Sawyer, 2003; 2012a, 231). Analysis covered periods where pupils were primarily working together rather than focusing on their own individual ideas. Pupils 
were sharing ideas both verbally and physically. The findings demonstrate that despite the challenges, the teacher trainees managed to create drama lessons that supported the pupils' group creativity.

\section{Conclusions}

The eight-videotaped lessons were analyzed by both authors separately to increase the reliability of the results. It was not always easy to determine the exact waiting, instruction or active working times. In some cases, groups start working at different times because the trainee was still giving instructions to others (e.g. cases 1 and 6). In other cases, the teacher trainee was using story telling as instruction making the interpretation of the activity difficult (e.g. cases 2 and 4). The researchers' dissenting findings (time indexing) made only a slight difference in all seven cases. In most of the cases, the difference between the time indexing between researchers in the whole lesson was one minute or less. The biggest difference, four minutes, was in case 5. That lesson contained a lot of interference and ambiguous situations that the researchers had interpreted differently. The lesson was analyzed and discussed together again to reach a consensus about the time indexing.

The research results show that the analysis method used was of moderate utility. The method of analysis is suitable for close reading of short and exact episodes (e.g. a half minute video sequence) to identify the basic elements of group creativity. The three characteristics (collaboration, improvisation and emergence) were perceived clearly even in situations where a class was working together. It should be noted when reading the results that the analysis did not concentrate on the quality of the pupils' creative work. The researchers did not evaluate the level of individual student engagement or the quality and originality of their creative solutions. The analysis focused on working sections where group creativity is likely to arise and be supported. During these periods pupils were primarily working together and sharing ideas both verbally and physically in pairs, small groups or as a class together with some drama convention. Teacher trainees used drama conventions to actively explore a text and its meanings. All the lessons were based on a children's book or story that had been read earlier for the classes. This procedure was based on the concept of 'little c creativity', LCC, defined by Craft $(2001,45)$. LCC refers to everyday creativity and it differs from 'big C creativity', BCC, which is defined as the generally acknowledged original work of creative geniuses. Children's creativity often differs from adult's creativity due to its subjectivity; children's creativity rarely meets the criteria of BCC creativity. (Craft 2001, 46; Toivanen et al., 2013a.)

The video analysis included a few scenes (working periods), which were challenging to decide whether they supported group creativity or not, e.g. Who is leading the movement -game in cases 1 and 5 , moving in the role in case 5 , individual characterization in case 5 and action narration in cases 3 and 8 . The researchers watched these scenes again together and discussed them from the perspective of the selected criteria. When the scenes had some indicators of all three aspects (improvisation, collaboration, emergence) they were categorized as a scene that supports group creativity. The decisive factor in these cases was teacher trainee's actions that support pupils' abilities to share their activities and solutions with each other. In the creativity cases the teacher trainee used forms (e.g. a circle) or gave instructions (e. g. Look around!) that supported sharing ideas between the pupils (collaboration). These were also examples of how group creativity supporting teaching is related to classroom quality. The teacher trainees' didactical solutions (selected exercises and drama techniques) and pedagogical relationship (group handling, behavior management, instructional support, learning climate) are important elements for creative pedagogy. These components were also revealed in our previous study (see Toivanen et al., 2013a). Additionally, it is important to remember that the correct analysis and solutions to all educational problems are not easy or predictable, because each classroom with students and each lesson is unique (Kagan 1992).

There are also factors this study does not take into account. It is important to note that we observed separate lessons instead of whole teaching periods. Furthermore, the observed lessons were from different times of the teaching period and this affects the time needed for instructions and managing the group. For example in case 5 the lesson started with making drama contracts since it was the first of their drama lessons. Group management was not very efficient as in some cases. Exact instructions take time, but they are necessary if the working methods are unfamiliar. When the pupils and the drama techniques were familiar, it seemed that fewer instructions were needed. We will carry on this research project by examining the same question with experienced drama teachers. We are interested to know whether there are any differences between an experienced and novice teacher's drama lesson from the perspective of group creativity? It would also be interesting to compare these results with another subject. How do teacher trainees succeed in supporting pupil's group creativity when they teach other subjects?

When starting drama with a new group, a teacher is always looking for a balance between exercises that improve pupils' ability to work together and drama techniques that support both individual and group creativity. In this study, we were interested in the working time that supports pupils' group creativity. A positive finding was that all studied drama lessons had working sections and used drama techniques that supported group creativity to the extent that in six cases it was the main part of the active working time. Only in cases 4 and 7 did creativity take under half of the active working time. In case 4 it was still 20 minutes (49\%), which was longer than in other lessons where the percentage was higher. The research gives encouraging results about the amount of group creativity during drama lessons. When examining the research results one have to remember that the main goal for teacher trainees in these lessons was to give pupils a possibility to process a children's book or a story and for themselves to practice drama teaching skills. Analysis also shows that different drama techniques emphasize different features. All of them do not support group creativity even though they give a possibility to work with roles in fictional time and space. Teachers should select interactive forms of drama technique to give their pupils possibilities to improve their group creativity.

Drama is the most social form of art education (Neelands 2004, 2). Within the restrictions of the case study, our conclusion is that drama teaching seems to support pupils' creativity. We focused on pupils' group creativity - i.e., their ability to create creative solutions together. As a social form of art education drama can support pupils' group creativity if suitable 
drama techniques are used. Group creativity should be one aspect of drama teaching that teachers should take into account when planning a drama lesson. Teacher should ask; which are the elements of my drama teaching that support my pupils' group creativity?

\section{References:}

[1] Bailin, S. (2011). Creativity and Drama Education. In Schonmann S. (ed.) Key Concepts in Theatre/Drama Education. (209-213). SensePublishers (Online).

[2] Barron B. \& Engle R.A. (2007). Analysing data derived from video records. In S.J. Derry (Ed.) Guidelines for Video Research in Education. (24-33). Data Research and Development Center: Chicago.

[3] Craft, A. (2001). 'Little c creativity'. In Craft A., Jeffrey B. \& Leibling M. (Eds.) Creativity in education (45-61). London: Continuum.

[4] Dickinson, R., Neelands, J. and Shenton Primary School (2006). Improve your Primary School through Drama. London: David Fulton Publishers.

[5] Dunn, J. (2008). Playing around with improvisation: an analysis of the text creation processes used within preadolescent dramatic play. Research in Drama Education: The Journal of Applied Theatre and Performance. 13(1), 55-70.

[6] Erickson, F. (2006). Definition and analysis of data from videotape: Some research procedures and their rationales. In J. L. Green, G. Camilli \& P.B. Elmore (Eds.), Handbook of complementary methods in education research. (177-205). Mahwah: Lawrence Erlbaum Associates.

[7] Halkilahti, L. (2013). Valokeilassa lasten luovuus: ryhmäluovuuden tukeminen draaman keinoin. [Children's creativity on the spotlight: supporting group creativity through drama.] Master thesis. University of Helsinki.

[8] Heath, C. (1997). The analysis of activities in face-to-face interaction using video. In D. Silverman (Ed.) Qualitative research: theory, method and practice. (183-200). London: Sage.

[9] Heddon D. and Miiling J. (2006). Devising performance. A critical History. London: Palgrave Macmillan.

[10] Hui A. \& Lau, S. (2006). Drama education: A touch of the creative mind and communicative-expressive ability of elementary school children in Hong Kong. Thinking Skills and Creativity. 1(1), 34-40.

[11] Johnstone, K. (2007). Impro: improvisation and the theatre. London: Methuen Drama.

[12] Jyrhämä, R. \& Maaranen K. (2012). Research Orientation in a Teacher's Work. In Niemi H., Toom A. and Kallioniemi A. (Eds), Miracle of Education. The Principles and Practices of Teaching and Learning in Finnish Schools. (97-114). Rotterdam: Sence Publishers.

[13] Kagan, D. M. (1992). Implications of research on teacher belief. Educational psychologist. 27(1), 65-90.

[14] Kampylis, P., Berki, E. \& Saariluoma, P. (2009). In-service and prospective teachers' conceptions of creativity. Thinking Skills and Creativity. 4(1), 15-29.

[15] Karakelle, S. (2009). Enhancing fluent and flexible thinking through the creative drama process. Thinking Skills and Creativity, 4, 124-129.

[16] Konstantinidou E., Gregoriadis A., Grammatikopoulos V. \& Michalopoulou M. (2013). Primary physical education perspective on creativity: the nature of creativity and creativity fostering classroom environment. Early Child Development and Care. http://dx.doi.org/10.1080/03004430.2013.818989

[17] Kurtzberg, T. (2005). Feeling creative, being creative: an empirical study of diversity and creativity in teams. Creativity Research Journal. 17(1), 51-65.

[18] Lin, Y.-S. (2011). Fostering creativity through education - a conceptual framework of creative pedagogy. Creative Education. 2(3), 149-155.

[19] Lobman, C. (2003). What should we create today? Improvisational teaching in play-based classrooms. Early Years: An International Journal of Research and Development. 23(2), 131-142.

[20] Lobman, C. (2005). "Yes and": The Uses of Improvisation for Early Childhood Professional Development. Innovations in Early Childhood Teacher Education: Reflections on Practice. 26, 305-319.

[21] Lobman, C. (2006). Improvisation: An analytic tool for examining teacher-child interactions in the early childhood classroom. Early Childhood Research Quarterly. 21, 455-470.

[22] McLauchlan, D. (2010). Collaborative Creativity in a High School Drama Class. Youth Theatre Journal. 15(1), 42-58.

[23] Moeller Andersen H. \& Lund Nielsen B. (2011). Video-Based Analyses of Motivation and Interaction in Science Classrooms. International Journal of Science Education. 35(6), 906-928.

[24] Neelands J. (2004). Beginning drama 11 - 14 (2nd ed.). London: David Fulton Publishers 
[25] Neelands J. \& Goode T. (2011). Structuring drama work. A handbook of available forms in theatre and drama (2nd ed.). Cambridge University Press: Cambridge.

[26] Pianta R.C., La Paro K.M. \& Hamre B.K. (2008). Classroom assessment scoring system. Manual K3. Baltimore: Paul $\mathrm{H}$. Brookes Publishing Co.

[27] Pirola-Merlo, A. \& Mann, L. (2004). The relationship between individual creativity and team creativity: aggregating across people and time. Journal of Organizational Behavior. 25, 235-257.

[28] Sawyer, R.K. (1997). Pretend play as improvisation. Conversation in the preschool classroom. Mahwah, NJ: Lawrence Erlbaum Associates.

[29] Sawyer, R.K. (2003). Group creativity. Music, theatre, collaboration. Mahwah, NJ: Lawrence Erlbaum Associates.

[30] Sawyer K.R. (2006). Group creativity: musical performance and collaboration. Psychology of Music. 34( 2), 148-165.

[31] Sawyer, R.K. (2012a). Explaining creativity. The science of human innovation (2nd ed.). New York: Oxford University Press.

[32] Sawyer, R.K. (2012b). Extending sociocultural theory to group creativity. Vocations and Learning. 5, 59-75.

[33] Spolin, V. (1999). Improvisation for the Theater (3rd ed.). Evanston, IL: Northwestern University Press.

[34] Tanggaard, Lene (2011). Stories about creative teaching and productive learning. European Journal of Teacher Education. 34(2), 219-232.

[35] Toivanen, T. (2013). Drama education - the Finnish (and Nordic) perspective. In Seghedin, E. \& Masari, G-A. (Eds.). Knowledge Based Society Teaching Profession Challenges. (239-254) Societate \& Cunoastere 29. Iaşi: Institutul European.

[36] Toivanen, T., Antikainen, L., \& Ruismäki, H. (2012a). Teacher's Perceptions of Factors Determining the Success or Failure of Drama Lessons. Procedia: Social and Behavioral Sciences. 45, 555-565.

[37] Toivanen, T., Halkilahti, L. \& Ruismäki, H. (2013a). Creative pedagogy - Supporting children's creativity through drama. The European Journal of Social \& Behavioural Sciences. 3(7). 1168-1179.

[38] Toivanen T. \& Kaasinen M. (2013b). Comparing body awareness between actors and drama teachers. Cognitive-crcs. 1(1). 4-9.

[39] Toivanen, T., Mikkola, K., \& Ruismäki, H. (2012b). Challenge of the Empty Space: Pedagogical and multimodal interaction in drama lessons. Procedia: Social and Behavioral Sciences. 69, 2082-2091.

[40] Toivanen, T. \& , Pyykkö, A., (2012c). Group Factors as a Part of Drama Education. The European Journal of Social \& Behavioral Sciences. 2(2), 150-168.

[41] Toivanen, T. \& , Pyykkö, A., (2012d). Challenge of the Empty Space: Group Factors as a Part of Drama Education part 2. Procedia: Social and Behavioral Sciences. 69, 2289-2298.

[42] Toivanen, T., Pyykkö, A., \& Ruismäki, H. (2011). Challenge of the Empty Space: Group Factors as a Part of Drama Education. Procedia: Social and Behavioral Sciences. 29, 402-411.

[43] Turner, M.E. (2008). Introduction. Social influence and creativity: setting the stage for inventiveness. Social Influence. 3(4), 223-227.

[44] Yin, R. (2002). Case study research: Design and methods (3rd ed.). London: Sage.

\section{Author' biography with Photo}

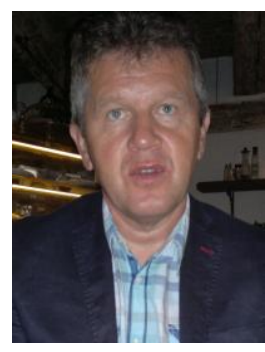

Tapio Toivanen, Assosiate Professor, Doctor of Arts in Theatre and Drama, University Lecturer of Drama Education, Department of Teacher Education, Faculty of behavioral sciences, University of Helsinki, Finland. Tapio Toivanen is first theatre pedagogy PhD graduated from the Theatre Academy of Helsinki (2002). He is interested in drama and theatre art-pedagogical research and has written a number of drama education-related books and scientific articles. 